\title{
The politics of space and mobility: controlling the Ooldea/Yalata Aborigines, 1952-1982
}

\author{
Maggie Brady
}

\begin{abstract}
In 1977 Isobel (Sally) White described the camp sites, spatial organisation and mobility of Pitjantjatjara-speaking people at Yalata, a community 1000 kilometres northwest of Adelaide, South Australia. She remarked on the unusual living arrangements of that community, in which the entire Aboriginal population was periodically relocated from one Big Camp to another somewhere on the Yalata reserve, 4650 square kilometres of land running east-west along the Eyre Highway. In this article, I show that the unusual arrangement she described did not arise spontaneously, but was one of several last-ditch strategies designed to force Yalata people to remain well south of the dangerous and prohibited area of the Maralinga atomic testing site. White observed and described this state of affairs without knowing its origins. She and the people with whom she lived up until the early 1970 s could also not have imagined that resettlement in the spinifex country of the Great Victoria Desert would eventually take place, and that there would be a reclamation of the wide-ranging mobility the people once had.
\end{abstract}

In 1949 one hundred and thirty Aboriginal men, women and children from the United Aborigines' Mission (UAM) station at Ooldea Soak became actors in the feature film 'Bitter Springs'. Accompanied by their missionary carers, they travelled east by train from Ooldea, on the edge of the Great Victoria Desert in South Australia, to the film site at Warren's Gorge, near Quorn. There, for the director Ralph Smart of Ealing Studios, they acted out a fictional dispossession of their land, a dispossession which was already taking place in real life.

'Bitter Springs' was billed as an action romance telling the story of a white Australian settler family who, accompanied by a flock of sheep and a trusty Aboriginal helper 'Black Jack', trek into unknown territory to take up land leased to them by the government for 80 pounds a year. 'You need land to grow, new land' announces Wally King (Chips Rafferty), the family head, as they set off to find a new home with reliable water. But things go wrong. They discover the perfect site, only to find the 'Karigani' tribe, played by the Ooldea people, ensconced at the desired waterhole of the film's title. Cautious hospitality is offered by the 'blacks' at first, but the settlers outstay their welcome and when they build a hut hostilities break out. Into this tense situation comes a firm but friendly trooper (Michael Pate), with some Aboriginal companions; he is knowledgeable and somewhat sympathetic to the local 'tribes'. He explains to the settlers that the springs have been a tribal home to the Aborigines for a thousand years, 
that 'the land's sort of sacred to them'. Wally King observes that the trooper seems to be on the blacks' 'side', but Pate responds by saying that his job is to protect both black and white. He does not suggest the settlers should withdraw, however. Instead he offers the headstrong King three options for dealing with the Aborigines: 'You can shove 'em off', he says, 'ease 'em off, or you can find some way of taking them in with you' - and through this advice he ultimately betrays the Aborigines. The story ends with the local tribesmen being 'taken in': working as shearers for the settlers. Released in 1950, the film parallels the fate of its Aboriginal protagonists over the subsequent three decades.

In the years that followed, the Ooldea people were both 'shoved' and 'eased' off large tracts of the Great Victoria Desert, their home. The UAM station was closed, a portion of their land was appropriated for atomic test sites at Emu and Maralinga, and the people were excluded from the sites and walking routes of their country. They were relocated further south, where new missionary carers, Lutherans, took them in and monitored their previously free-ranging mobility.

\section{Closing the mission}

The mission station from which the film directors selected their Aboriginal cast was a tenuous outpost on the edge of a waterless stretch of the Great Victoria Desert. Aboriginal groups of the western desert bloc had been walking in and out of the Ooldea Mission since ration distribution first commenced there in 1933, and had used the permanent water of the Ooldea Soak for centuries before that. ${ }^{1} \mathrm{~A}$ few kilometres south of Ooldea, the Trans-Australian railway line, running east to Port Augusta and west to Perth, had also attracted Aboriginal people since its construction between 1912 and 1917. As a result of the impact of the railway line construction, Daisy Bates selected Ooldea as the location for her work among the 'natives', and camped there between 1919 and 1935. The UAM set up dormitories for Aboriginal boys and girls, ran a boys' brigade and a school, conducted Christian services and distributed rations. During the UAM's tenure of nearly twenty years, several hundred desert people came in out of the desert on a permanent or semi-permanent basis. ${ }^{2}$ Indeed, many of those who played the 'wild blacks' in 'Bitter Springs' had themselves only recently come from the spinifex country. These people were travellers of great distances over harsh country. The walking routes to Ooldea from the north and northwest were dotted with rock-holes, many of which could be dry on occasions. Ooldea itself, Tjintakara (west of Serpentine Lakes) and Wantu (north of Cook) were some of the few permanent waters. In later years people described that they drank from water roots to survive the last waterless leg of the journey to Ooldea. Ronald and Catherine Berndt noted in 1941 that there was movement out of Ooldea altogether and into the spinifex after good rains; on one occasion out of a population of approximately 200 people at the Soak, 120 left for the spinifex ${ }^{3}$. The railway was rapidly taken up by Aboriginal people as a means of transport. It provided passage (in open wagons) to and from Cundeelee in the west for ceremonial visits. From Cundeelee (Western Australia) people travelled north, to the Warburton region. Desert people also travelled east by train to Tarcoola to attend ceremonies in the

1. Bolam 1923; Bates 1938.

2. Brady $1987 \mathrm{a}$.

3. Berndt and Berndt 1942a. 
region between Bulgunnia station and Coober Pedy. Ironically, the existence of the railway was to be a major reason for the selection of the atomic test site which came to be known as Maralinga - a site which lies just north-west of Ooldea - and which was the cause of their eventual exclusion from the land.

There had been failed attempts over several years to relocate the UAM mission to a more hospitable spot, but the missionaries running the Ooldea outpost lost out altogether when the establishment was forced to close down suddenly (as a result of internal politics within the UAM) in June 1952, and 'their people' were handed over to a rival group, the Lutherans. At the closure of the mission, rations were distributed for the last time and several large contingents of Ooldea people set off by train to live with kin in Cundeelee, and in Ernabella. A new property for the Ooldea Aborigines had been purchased, together with 7000 sheep, by the South Australian government in advance of these developments (in March 1951), which was to be managed by the Lutheran Evangelical Church. The property was part of Yalata Station, $140 \mathrm{~km}$ south of Ooldea on the edge of the Nullarbor Plain, on country alien to desert people. Only a few dozen Ooldea people remained after the large groups had left for elsewhere, and this small group was hurriedly transported to Yalata (amid considerable confusion) by local Lutherans. A large group of about one hundred people - who had already started the journey to their chosen destination of Ernabella - was rounded up over the next few weeks, and deposited at Yalata. This task was accomplished by the native patrol officer employed by the Woomera authorities.

\section{Curbing Aboriginal mobility - the role of MacDougall}

Like the trooper in 'Bitter Springs', Water MacDougall, the native patrol officer who had most to do with the Ooldea people, was caught between his sympathies for the Aborigines and the exigencies of his job.

MacDougall was a middle-aged man who had spent three years as stock manager at Ernabella, a Presbyterian mission in northern South Australia. ${ }^{4}$ The Commonwealth authorities initially approached Syd Kyle-Little (a Northern Territory patrol officer with experience of several long foot patrols in Arnhem Land ${ }^{5}$ ) for the job. In the end, MacDougall was hired in November 1947. He was employed as a native patrol officer by the Weapons Research Establishment (WRE) ${ }^{6}$ at Woomera (then engaged in a guided missile testing program) to control any interference with the "habits of Aborigines and any areas of special interest to them'. To this extent his job was similar to that of the Northern Territory patrol officers appointed by the Commonwealth, who aimed to protect the traditional lifestyle of Aboriginal people and counter the influences which were impelling them to leave their country. ${ }^{8} \mathrm{He}$ was also appointed as a Protector under the South Australian Aborigines' Act, so he reported to the Aborigines Protection Board as well as

\footnotetext{
4. Eames and Collett 1985: 29.

5. Long 1992: 58.

6. The Long Range Weapons Establishment was formed in 1948, and was reorganised in 1955 to produce the Weapons Research Establishment, with headquarters in Salisbury north of Adelaide. For consistency I have referred throughout to WRE.

7. Aboriginal Collation: 17 (10 March 1947).

8. Long 1992.
} 
to the Woomera Superintendent. At times it was unclear exactly to whom he was responsible. Ultimately, though, it was

the wishes and policies of Government to which he [MacDougall] adhered, rather than to the wishes of Aborigines...[D]ifferences with his employers arose because he believed it should be possible to serve the interests of both Government and Aborigines, if only Government policy was consistent and principled. MacDougall objected when Government failed him in this, but he nevertheless proved himself ready on a number of occasions to interfere substantially and persistently in Aboriginal lifestyles and wishes when he believed Government policy and need so dictated. ${ }^{9}, 10$

We know from his reports to the WRE that MacDougall became increasingly alarmed at his employers' earlier assumptions that there was only limited movement by Aborigines in the Woomera region, that people were largely 'detribalised', and that they were no longer living off the land or engaging in much ceremonial activity. His own work convinced him that these assumptions were incorrect, for he found that there was considerable movement between the Everard and Musgrave Ranges to the north and the Trans-Australian railway to the south, and that many groups still lived in the desert, walking into Ernabella and other locations on occasions to bring in dingo scalps in exchange for rations. He wrote exasperated and critical memos to his employers, who did not see fit even to provide him with a vehicle of his own for three years. He began to suggest ironically that perhaps he should use camels. ${ }^{11}$ On many occasions his advice was simply ignored.

MacDougall's main concern was safety. He was supposed to be protecting Aborigines from the incursions of the WRE, but in reality his job was to control the movement of the populations of Aboriginal people on the fringes of, and sometimes inside, the Woomera Rocket Range (between 1947 and 1952), and later the Maralinga/Emu atomic testing area, (used between 1953 and 1962). He was faced with several hundred highly mobile desert people, many of whom had limited interaction with white Australians, and who were still engaged in a vigorous ceremonial life spanning a vast area of South Australia and Western Australia. They had long used the railway to facilitate ceremonial visits. Historical research undertaken in the lead-up to the Royal Commission into the British Nuclear Tests in Australia ${ }^{12}$ enabled a clear picture to emerge of the strategies MacDougall developed in order to control Aboriginal movements. He used three interlocking techniques: the withholding of rations, the manipulation of Indigenous beliefs and direct interception of movement.

9. Eames and Collett 1985: 30.

10. MacDougall was the cause of the famously callous statement made in March 1956 by Mr A. Butement, Chief Scientist of WRE, who referred to his 'lamentable lack of balance' for 'apparently placing the affairs of a handful of natives above those of the British Commonwealth of Nations'. MacDougall was particularly incensed at the siting of Giles Weather Station and the upgrading of an existing track to the Central Aboriginal Reserve in 1956. He said the land belonged to the tribe and was recognised as such by other tribes (Morton 1989: 85,87).

11. Eames and Collett 1985: 34 .

12. This included research by Dr Heather Goodall and myself, much of which is incorporated into Eames and Collett, 1985. 


\section{Shoving them off - rations and interceptions}

In the early 1950s ceremonial activity was strong, with frequent departures of large groups of people from Ooldea (until June 1952) and Yalata (after that time). These trips meant that groups of Aborigines were often gathered at railway sidings such as Watson, Ooldea and Tarcoola (adjoining the prohibited area), and were often on foot or in trucks in the Lake Phillipson area (near Coober Pedy). Woomera and Department of Supply papers document these movements, which took place throughout the Woomera rocket testing program, and the subsequent Maralinga atomic testing program. For example, three groups walked from Yalata to Ooldea siding in order to travel by train east and west (January 1954). One hundred and fifty people visited Ooldea Soak and 60 travelled to Coober Pedy (October-November 1954); 100 adults and children assembled at Ooldea siding awaiting the arrival of parties from Western Australia in order to travel to Tarcoola (August 1955); and in October 1955, 80 people were at Ooldea siding waiting for the train to Zanthus, Western Australia. In August 1956 a Lutheran pastor reported plans for 200 Yalata people to travel to Deakin siding (Western Australia) by train, in order to walk north to Warburton. ${ }^{13}$ The superintendent of the range insisted that these 'itinerants' should be controlled. MacDougall recommended that a checkpoint be constructed at the railhead and passes issued to those taking the train.

MacDougall knew that the provision of rations was an instrument of enticement for desert people. Ooldea Mission itself had been an attractive force since 1933, with visitors returning to the desert carrying bags of flour on their heads so that their relatives could 'taste' the new substance. ${ }^{14}$ The Berndts wrote in 1942 that the Ooldea people placed 'great reliance on their government rations. They regard them as a full food supply and they refuse to supplement the diet with native foods, as this would be too much bother'. ${ }^{\prime 5}$ MacDougall recommended in 1950 that ration depots should be closed around the arc from Ooldea, through Bulgunnia Station to Mabel Creek. He wanted Ooldea closed and declared off-limits because of his concerns that it acted as a steppingoff point, particularly towards the northeast, into the weapons testing area. ${ }^{16} \mathrm{He}$ later cut the ration issue at Coober Pedy, and in 1955 no rations were issued for people intending to travel north out of Yalata.

\section{Easing them off by exploiting Indigenous fears}

Among Aboriginal people who were cognizant of developments, there was undoubtedly fear of what was occurring at Maralinga which acted as a deterrent against utilising the old walking routes which linked the Ernabella region with Ooldea. These fears became manifest in the many stories and rumours which touched upon the bomb tests at the time, and which were later to be associated with the contamination of the land by

13. These movements are all documented in patrol and other reports retrieved for the Royal Commission (Eames and Collett 1985: 42; 56-57).

14. Brady 1987a; cf. Rowse 1998.

15. Berndt and Berndt 1942a: 59. The derogatory tone of this observation is surprising considering the Berndts' own fieldwork documented continued hunting and gathering among the people visiting or residing at Ooldea. The fact that rations there did not include meat gave people an additional impetus to hunt for red kangaroo and other prized meat. Certainly in later years the desire for hunted meat had not abated, cf. Palmer and Brady 1991.

16. Eames and Collett 1985: 33. 
radioactive waste. Radioactivity became known universally at Yalata as the 'poison'. The southeastern portion of the Great Victoria Desert through which these groups travelled is believed by them to be inhabited by numerous wanampi (the desert term for a dangerous water serpent or rainbow snake). These mythological beings are believed to have travelled over and under the ground and created the landscape over wide swathes of the Great Victoria Desert, including some notable sites well-known to the Ooldea and Yalata people. The salt lake at Pidinga (Ifould Lake), between Yalata and Ooldea, is such a site. The Nullarbor is riddled with blowholes where more wanampi are reputed to live. Elderly people now living at Yalata express fear of these beings and describe placating them or firing large trees in order to frighten them with smoke. Unlike later patrol officers who attended courses at the Australian School of Pacific Administration in Mosman, Sydney, MacDougall had no anthropological training, although he probably had some facility with the Pitjantjatjara language. Nevertheless, he conceived of an innovative technique which utilised Indigenous beliefs as a means of frightening desert people away from the atomic testing area. He would have heard mythological stories of wanampi and of kurdaitcha men while at Ernabella, and in a 1953 report he explained that 'using their own beliefs and fears of invisible spirits and invisible avengers [will] convince them that the area is no safe place for them' ${ }^{17}$ In many cases, wanampi stories have now become enmeshed with the warnings, rumours and half-understood facts of contamination associated with the Maralinga tests. ${ }^{18}$ MacDougall's idea evidently bore fruit. Kanytii, one of the Aboriginal people living at Wallatinna, northeast of Emu (which was affected by the 'black mist' of contamination after the Totem 2 test of October 1953) described hearing a sound early in the morning, which was in fact the bomb:

He thought it was someone shooting. Then he thought it may have been the wan$a m b i$, the water serpent of the Dreamtime, making a noise as it created water holes. Pingkayi also heard two noises as did Kanginy who was inside the homestead at the time. Kanginy also associated the noise with wanambi [sic]. ${ }^{19}$

And at Yalata, contemporary stories ${ }^{20}$ associated with wanampi include the following:

One piranpa [white man] was travelling with camels. They only found the saddles. He never came back. Wanampi must have got him.

Wild horses disappeared at Puntja [a rock-hole north of Maralinga and in the contaminated area] - might be snake too.

Four soldiers in a Land Rover disappeared near wanampi ngura [camp of a mythological snake]. No one goes there now.

Two white people from overseas wanted to go and have a look at Maralinga. They told them: 'Don't touch anything. Don't break sticks'. But they said 'I can't die' and they broke sticks and their arms went numb. And they said 'we want to go home to our families because we might die'. And they went back overseas and they died.

17. MacDougall, Detailed survey of the Jangkuntjara Tribe, Report to WRE, April/May 1953.

18. A 1956 patrol report noted that a Cundeelee man returned from Yalata (i.e. at the time of the tests) and had several injections which he believed were to protect him from the effects of a Maralinga bomb (Eastern Goldfields District Office report September 1956, in Aboriginal Collation 1985).

19. Eames and Collett 1985: 138. A photograph of the windshear on the Totem 2 test cloud (which shifted to the north-east) appears in Symonds 1985: 211.

20. MB's field notes 1985, cf. Brady $1987 \mathrm{~b}$. 


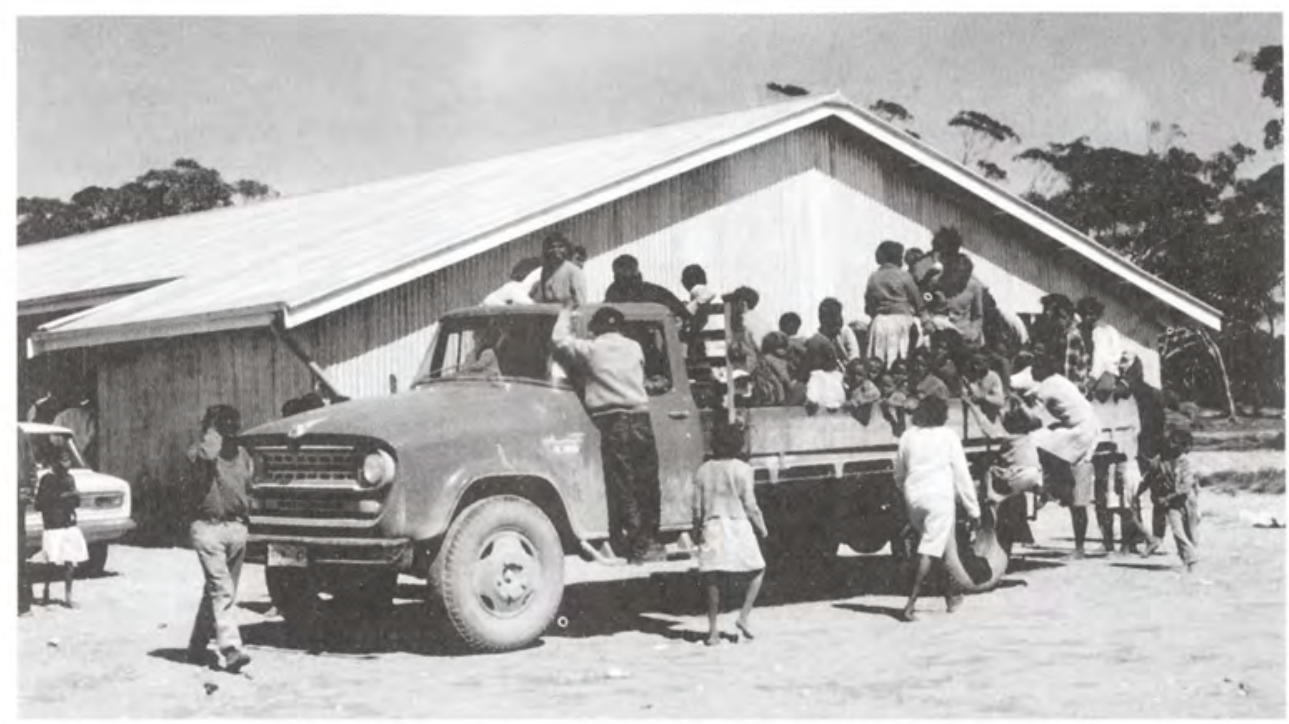

The Yalata mission truck laden with occupants, 1969.

(Photograph: I.M. White, reproduced with the kind permission of AIATSIS.

\section{Taking them in - Big Camp}

After the closure of Ooldea in June 1952 and the subsequent move to Yalata, it became clear to the missionaries and to MacDougall himself that the people did not want to stay there, on the powdery grey soil of the Nullarbor edge. They were homesick for Ooldea, they preferred the red sand and spinifex of the desert, and wanted to keep moving. MacDougall was partly responsible for the move south, having been enthusiastic in 1950 when it was suggested that the Yalata pastoral property be purchased as a new location for the Ooldea people. In 1954 (with the Maralinga site already chosen and named) and utilising his knowledge of Aboriginal Law, he had tried to bring about an emotional and spiritual 'closure' of associations with Ooldea by making sure that all ritual paraphernalia secreted in the surrounding bush had been retrieved, taking several older men with him on a special 'clean-up' trip. They visited several initiation sites and an increase site. The ritual objects had been left there, in hiding, since the relocation to Yalata 18 months earlier. While he conceded that Aboriginal interest in the sites around Ooldea was 'more than sentimental', MacDougall simultaneously believed that this 'interest' could be redeposited onto new ceremonial grounds at Yalata, and had searched for suitable locations there. His report that 'all active tribal interest' in the Ooldea region was at an end made the way clear in February 1954 for the old Ooldea reserve to be revoked, so that it could be used for any desired purpose by WRE. ${ }^{21}$ By this time, preparations at Maralinga were well under way. ${ }^{22}$ The Lutheran missionaries

21. It is worth noting here that MacDougall's view was that the Ooldea people were already 'detribalised', describing the people along the Trans-Australian line as 'useless outcasts', in contrast with the 'shy' and 'primitive' Aborigines he encountered on patrols much further north (Eames and Collett 1985: 70.)

22. The Prime Minister had agreed on 25 October 1953 to hand over Maralinga for the testing program (Eames and Collett 1985: 54). 
were instructed to monitor closely Aboriginal movements in and around Yalata and report on their planned excursions.

Despite this supposed end to their 'tribal interest', the ex-Ooldea people demonstrated their displeasure at their new home by voting with their feet. They made persistent attempts to travel north, back to Ooldea and more familiar territory. Several Aboriginal parties escaped from Yalata and had to be retrieved by the Lutherans (Hans Gaden, pers. comm.). During the summer of 1954-1955 the Lutherans reported that many of the four hundred 'Yalata' Aborigines moved 'to outlying districts' ${ }^{23}$ The determined efforts by the people to return to the Ooldea region, to the north - indeed anywhere other than the Yalata property on which they had been settled - caused consternation in WRE and the Aborigines Protection Board. On 4 November 1955 MacDougall noted in a memo to the Woomera Superintendent that the Aborigines Protection Board secretary wanted to visit Yalata in order to 'see first hand what is required to force these people to remain on their new country'. With respect to the problematic tendency of the ex-Ooldea people to wander north into danger, he came up with a plan which seemed to fit with Aboriginal inclinations, and which would keep them occupied on the Yalata property and away from Ooldea. His plan would satisfy the traditional desire of these Western Desert people to be on the move, while simultaneously conforming to the instructions of his employers. He proposed a form of rotational camping sites within a defined boundary, and wrote to the Woomera superintendent:

The Yalata property was thoroughly investigated as country suitable for semi tribal natives ... Several old shed tanks were visited and it was decided to establish them as periodical ration depots thus ... lessening the tendency to travel north towards their old hunting grounds (Aboriginal Collation 1985: 555).

The suggestion was put into practice. Over the next few years, the newly arrived desert people camped in small family groups housed in wiltja (humpies of branches and tarpaulins) loosely ranged around one of several 'shed' water tanks (simply a large sloping corrugated iron roof which collects rainwater into one or two water tanks below ${ }^{24}$ ). They were supplied with rations delivered by the missionaries. The arrangement came to be known as Big Camp (Pitj. ngura pulka). Not only did the Big Camp idea suit the Woomera authorities, at the time constructing the new atomic proving ground at Maralinga, it suited the Aborigines' new carers, the Lutheran missionaries, who were anxious to maintain control over the movement and location of their charges. They were also anxious to demonstrate their willingness to cooperate with WRE, whose personnel visited in military vehicles and helicopters to check on the movements of Aboriginal people. ${ }^{25}$ Once the procedure had been established by MacDougall, the location of camp sites and timing of the moves were decided 'in consultation with' the Lutheran superintendent of the mission. It allowed the Aboriginal people some freedom - albeit

23. Hampel 1977: 27.

24. These tanks included Ooldea Tank, Monburu Tank, Tallawan Tank, Middle Yard Tank, Nanwarra, Chinalumba. Shed tanks were a common means of collecting water on the far west coast of South Australia (Faull 1988). They have been reinstituted as a means of providing significant water catchment for Aboriginal people now living in, and travelling through, the southern portion of the Great Victoria Desert. A number have been built in the Oak Valley region since 1986 .

25. Hampel 1977: 38. 


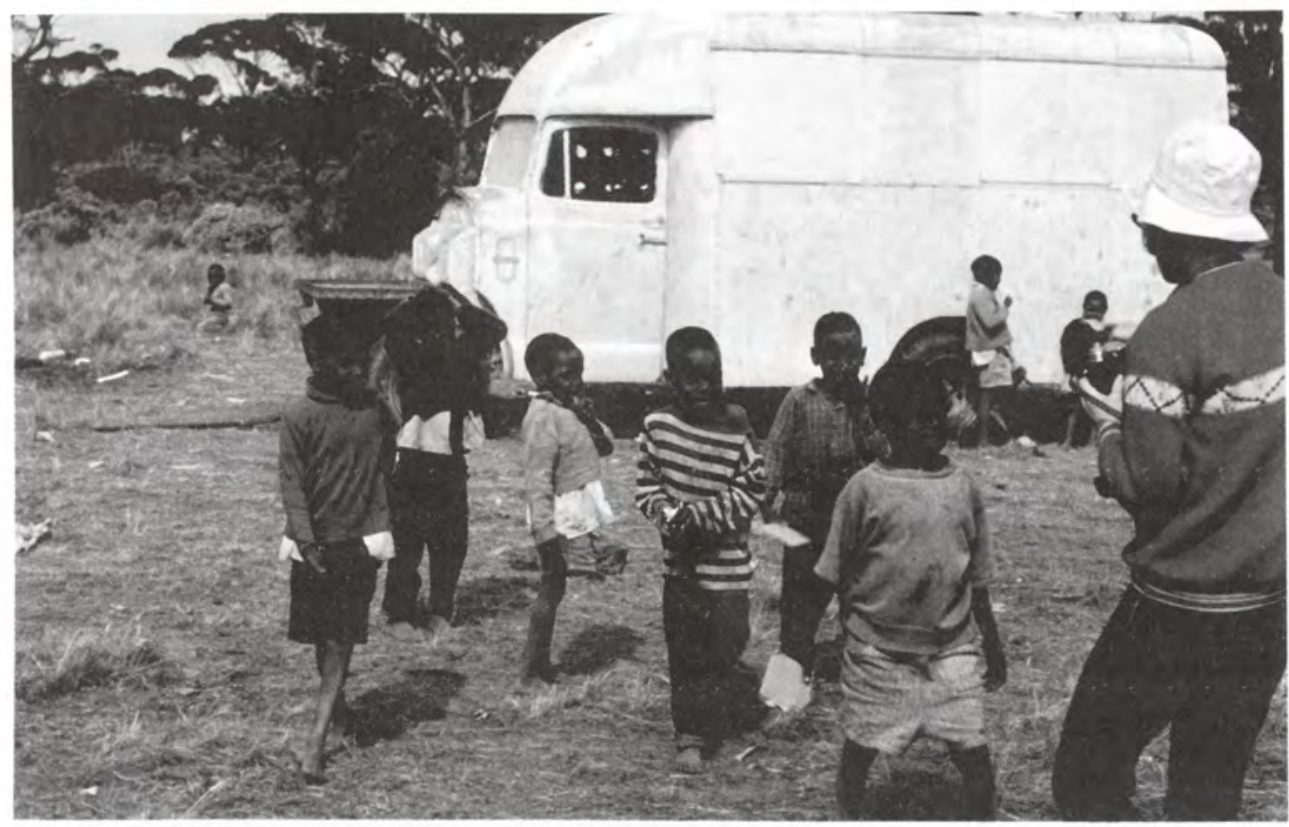

Margaret Kartomi with Yalata children at Big Camp near the mobile store.

(Photograph: I.M. White Collection, courtesy of AIATSIS)

restricted to the new country - which was designed to satisfy their thirst to be mobile. They were penned in, not by fences, but by the need for water supplies, their dependence on European rations, and the surveillance of the missionaries. In a final ironic twist the missionaries, like the settler family in 'Bitter Springs', tried to use Aboriginal labour for shearing sheep which grazed the eastern area of the property, near Colona. ${ }^{26}$. The Ooldea people had finally been 'taken in'.

Isobel White was the first anthropologist to camp out with families at Big Camp. She visited Yalata first in 1969 and pitched her tent at Big Camp, usually with Alice Cox and her family. ${ }^{27}$ The Lutherans were not keen to have her there at all, particularly when they knew she was from Monash University (which had a reputation for radical student politics in the late 1960s). ${ }^{28}$ She made porridge every morning to share among those at her camp. In 1977 White wrote that Yalata was an unusual settlement,

in that the whole camp moves several times a year to a new part of the reserve, which may be as far as 30 kilometres ( 20 miles) from the Yalata Lutheran Mission, but more often 6 to 20 kilometres away. This unique situation comes about through the active co-operation of the mission superintendent and his staff (some of whom are Aboriginal), who undertake the considerable task of organising

26. Hampel 1977: 35.

27. White 1985.

28. Sally White, pers. comm. The mission authorities would have been even more nervous had they known that Mrs White had been a member of the Communist Party. Many Lutherans of the time believed that Aborigines were 'communists' in that they had no individual property ownership (Brauer 1956: 175). 


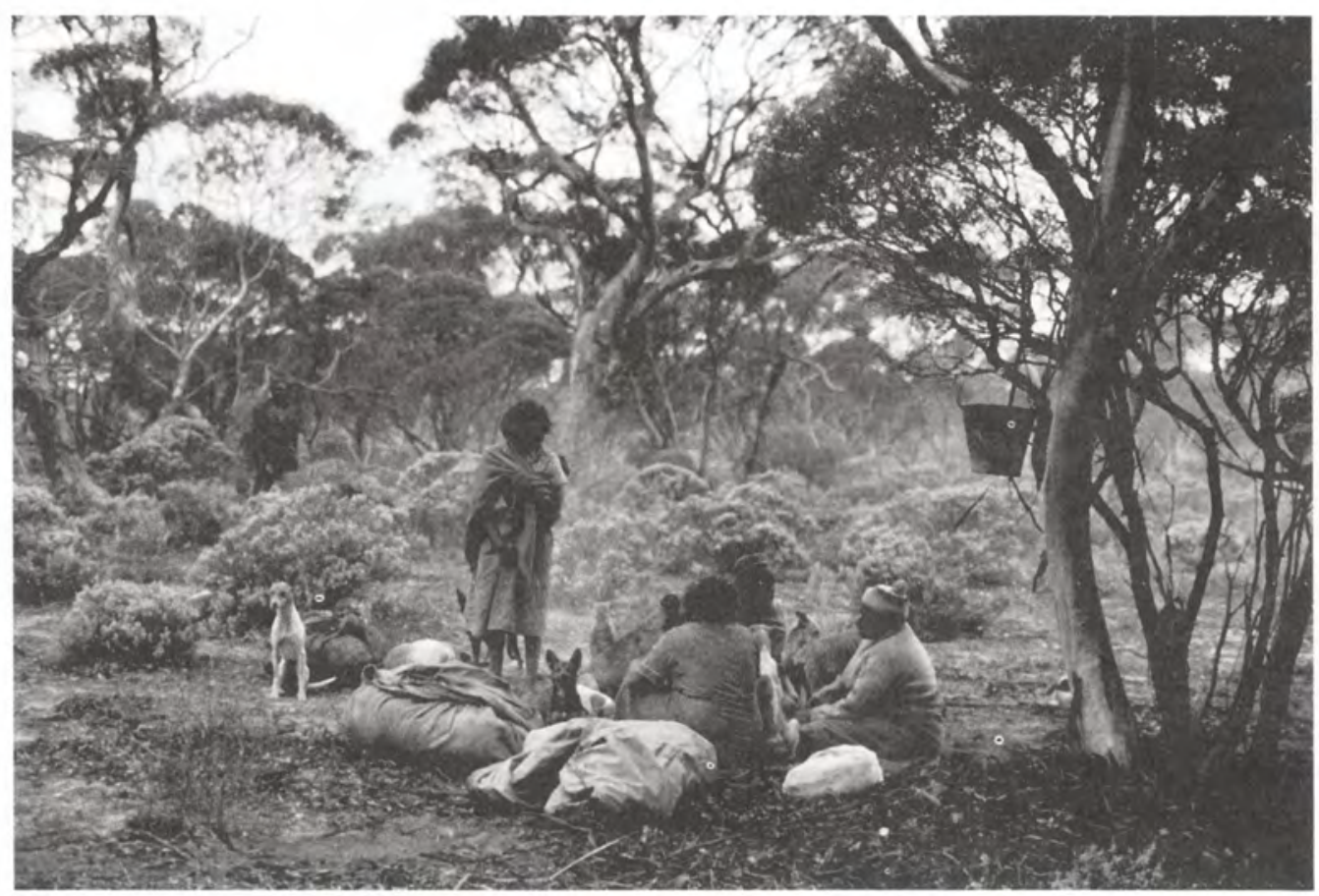

Yalata people at Big Camp.

(Photograph: I.M. White collection, courtesy of AIATSIS)

transport between camp and mission, because they see the advantages of using a large part of the reserve instead of only a small fraction of it. ${ }^{29}$

White was unaware that the original notion of Big Camp was a ploy to keep people south of the railway line.

\section{Moving camp}

Big Camp was usually located several kilometres - sometimes up to 30 - away from the Yalata settlement where the non-Aboriginal Lutheran and other staff lived in houses. The camp was invariably located at different sites north of the Eyre Highway, towards the desert and away from the coast. It moved several times a year to a new location, with the aid of community trucks and private vehicles. A mobile clinic and a mobile store were stationed centrally, opened for business three times each week and moved with the camp to new locations. There was even a 'walkabout school': 'Every time the camp shifted, it was necessary to pack up desks and teaching equipment, bathing and cooking facilities and move on to the next spot usually about 20 miles away. This happened about once ever four months' ${ }^{30}$ Along with the water truck, these facilities aided the plan to keep people together, and to prevent them from straying north. Once the services at Yalata became more developed in the 1960s, children were picked up from Big Camp each day by the school bus and taken to school in Yalata. Often only elderly people and their dogs remained at camp during the day. 
Living at Big Camp makes the observer acutely aware of its constant flux. White documented the requirements for a new camp site (on a used track, with trees for shade and firewood, and not having been used previously), and the composition of the hearth groups which made up Big Camp. She hypothesised that the movement itself was, in effect, a health promotion activity, noting that adjustments to physical and social distance had long been a form of stress management, and that moving camp improved physical, mental and social health. All these factors undoubtedly influenced the moves, but in the 1960s the decision to relocate was not made independently by Aboriginal people. The relocation of Big Camp which then occurred 'several times' a year was under the control of the Lutheran superintendent, who was in charge of the various supply trucks. In contrast, between 1978 and 1982 (during my own fieldwork) moves became much more frequent. Together with major shifts of Big Camp, individual hearth groups engaged in smaller 'creeping' relocation and reorientation of their camps which were continuous. People lived for the most part in easily-constructed wiltja which can be quickly demolished or were simply abandoned still standing. They can be reoriented when the wind swings around (weather fronts approaching from the Great Australian Bight cause dramatic changes in wind direction and temperature at Yalata). Abandoned wiltja were still considered to be the property of the former inhabitants, who would return to search for implements lost in the sand, or for a forgotten pot. In hot weather, hearth groups simply slept out next to a windbreak (yuu). Several factors may have influenced this increased mobility: the people themselves had more independence with the diminution of control by a superintendent (as Aboriginal self-management policies came into operation). There was the advent of more Aboriginal-owned vehicles, and the provision of smaller transportable water tanks which could be relocated at will using tray-back vehicles. I estimated that the hearth group with which I lived (1981-82) moved at least 20 times over a twelve-month period, that is approximately every 18 days.

This constant mobility is remarkably similar to how people lived in and around Ooldea Soak up until 1952. When Ronald and Catherine Berndt camped with people there in 1941, the camps moved so frequently that the anthropologists had trouble keeping up. The Berndts counted thirteen moves over a six-month period - a move approximately every two weeks. The distances involved ranged from a few metres to up to three kilometres away. The reasons for moving camp documented by the Berndts included lack of firewood, sanitation, too many people, ceremonies, death and stress. ${ }^{31}$ Forty years later, access to cars enabled the Yalata people with whom I camped much great freedom: the distances involved in their relocations ranged from two to thirty kilometres. But the reasons for moving were much the same as before, and I was told we moved because of lack of firewood, too much dust, wind or noise, too many drunks, too many kids, because of mice in the camp (on one occasion), to enable access to artefact wood, and because of a death or ceremonies. An additional but unspoken reason for moving seemed to be that people simply enjoyed it. Moving camp punctuated an otherwise mundane existence with a series of decisive tasks and a change of scene. Deciding on the move, selecting the new site, loading up the paraphernalia of the camp and rearranging it all again, burning the new site if there were snakes around, breaking 
branches for new wiltja, were all tasks that needed attention. Jean Briggs once observed of the peripatetic Inuit group with whom she lived, that rearranging the environment in this way is a form of play. ${ }^{32} \mathrm{I}$ am inclined to agree with her.

White's 1977 article on mobility at Yalata briefly addresses the issue of housing, which was then not available for the population en masse. Two or three families had houses in the Yalata township during White's fieldwork in the 1960s and 1970s, but people did not really live in them; they were referred to as 'wet weather houses', only being used on those occasions. She notes the advantages of wiltja: they do not require cleaning, they are flexible in size and orientation, they enable a change of neighbours, and they allow for relocation to an entirely new environmental space. Above all, they allow individuals to see and hear what everyone else is doing: to witness, to be there when things happen. ${ }^{33}$ White calls this 'first hand living'. Houses, she wrote, have none of these attributes. Nevertheless, the majority of Yalata families now have access to a house in the township, as a result of a determined housing program over the last 15 years.

When Sally White described the spatial arrangements of the Yalata Big Camp in 1977, neither she nor the people of whom she wrote had any idea that one day there would be a new settlement, $400 \mathrm{~km}$ away in the Great Victoria Desert. Since $1982 \mathrm{Big}$ Camp has ceased to exist. People moved closer into Yalata after a series of truck and other breakdowns that interrupted the servicing of Big Camp. Simultaneously people took up with alacrity the freedom to move which was made possible by social and political change in the 1980s. At the first real opportunity (a sympathetic community adviser) and in conjunction with discussions over their freehold title to the Maralinga Lands, people from Yalata established a camp that became an outstation, and is now rapidly growing into a township on the Maralinga Lands. This move both symbolised and enacted their rights to this land. The outstation is located between two salt lakes, Lake Dey Dey ${ }^{34}$ and Lake Maurice, both sites with mythological stories associated with them. Some parts of Dey Dey are restricted so that only initiated men may have access. From 1982 substantial numbers of people began to camp and visit the outstation which was known simply as 'Dey Dey'. Two years later, Dey Dey as the name for the outstation was abandoned by mutual agreement, having been declared a milmilpa (forbidden) term for a camp. A new decisively secular name, 'Oak Valley', was found for the outstation. Oak Valley has a core of permanent residents and a continuous stream of visitors from Yalata and elsewhere who stay for periods of a couple of days to months at a time. ${ }^{35}$ The descendents of the Ooldea people can now travel from Oak Valley to the west and then north to Warburton, on a new road they cut through the desert. They can receive ceremonial and other visitors by the same route. In a sense, people have reconstituted the social and cultural space they once had. As one man said, 'Big Camp has moved to Oak Valley'.

32. Briggs 1978 .

33. Sansom 1980.

34. Dey-Dey is an anglicised form of the Pitjantjatjara $₫$ tii-tii (magpie lark), a mythological character associated with the salt lake.

35. In four censuses of the population in 1987-8, a colleague and I counted 286 different individuals who were living in or visiting Oak Valley at any one time (Palmer and Brady 1991). 
It is not unlikely that the trooper of 'Bitter Springs' was a character modeled on Walter MacDougall, native patrol officer. The film was made two years after MacDougall's appointment, and was filmed in the outback not far south of Woomera itself. Unlike the Northern Territory, there were no other individuals operating as cultural brokers in this way in South Australia at the time. ${ }^{36}$ Like the trooper, MacDougall was a man who attempted his own rapprochement between the realities of white incursion and the uncomfortable situation in which Aboriginal people found themselves as a result. He also betrayed the Aborigines to some extent - an unpleasant necessity for reasons of safety - by participating in their exclusion from the southern portions of the desert, encouraging their relocation on alien territory, and inventing his own form of culturally appropriate compromise for their future. In the event, the inception and continuation of Big Camp suited people. As Sally White described, Big Camp allowed the ex-Ooldea people a certain freedom of movement, a means of dealing with interpersonal stress, and enabled them to create an Aboriginal domain away from the white staff of the settlement. In later years, the deeply embedded and unquenched desire for movement was enacted in the decision to resettle on the Maralinga Lands.

Maggie Brady is a social anthropologist and a Visiting Research Fellow at the Australian Institute of Aboriginal and Torres Strait Islander Studies in Canberra.

\section{References}

Aboriginal Collation. 1985. Collation of documents pertinent to Aboriginal submissions to the Royal Commission into British Nuclear Tests in Australia. Australian Institute of Aboriginal and Torres Strait Islander Studies library, Canberra.

Bates, D.M. 1938. The passing of the Aborigines. A lifetime spent among the Natives of Australia, J. Murray, London.

Berndt, R.M. and Berndt, C.H. 1942a 'A preliminary report of fieldwork in the Ooldea region, western South Australia. Acculturation and Native policy'. Oceania XIII(1): $51-70$.

Berndt, R.M. and Berndt, C.H. 1942b. 'A preliminary report of fieldwork in the Ooldea region, western South Australia. Introduction'. Oceania XII(4): 305-330.

Bolam, A.G. 1923/1978. The Trans-Australian wonderland. University of Western Australia Press, Nedlands, facsimile edition.

Brady, M. 1987a. 'Leaving the spinifex: the impact of rations, missions and the atomic tests on the southern Pitjantjatjara'. Records of the South Australian Museum 20: 3545.

Brady, M. 1987b. 'Dealing with disorder. strategies of accommodation among the southern Pitjantjatjara, Australia'. MA thesis, Australian National University, Canberra.

Brauer, A. 1956. Under the Southern Cross: history of the Evangelical Lutheran Church in Australia. Lutheran Publishing House, Adelaide.

Briggs, J. 1978. Never in anger: portrait of an Eskimo family. Harvard University Press, Cambridge, Mass.

Eames, G.M. and Collett, A.C. 1985. Final submission by Counsel on behalf of Aboriginal organisations and individuals to the Royal Commission into British Nuclear

36. A second patrol officer, R.A. McAuley, was employed in 1956 
Tests in Australia.

Faull, J. 1988. Life on the edge: the far west coast of South Australia. District Council of Murat Bay, Ceduna.

Hampel, Pastor N.A. 1977 Yalata Lutheran Mission 1952-1977. Yalata, South Australia.

Long, J.P.M. 1992. The go-betweens: patrol officers in Aboriginal Affairs Administration in the Northern Territory 1936-74. North Australia Research Unit, Darwin.

Morton, P. 1989. Fire across the desert: Woomera and the Anglo-Australian Joint Project 19461980. Department of Defence, Canberra.

Palmer, K. and M. Brady. 1991. Diet and dust in the desert: an Aboriginal community, Maralinga Lands, South Australia. Institute Report Series, Australian Institute of Aboriginal and Torres Strait Islander Studies, Canberra.

Rowse, T. 1998. White flour, white power: from rations to citizenship in central Australia. Cambridge.

Sansom, B. 1980. The camp at Wallaby Cross: Aboriginal fringe-dwellers in Darwin. Australian Institute of Aboriginal Studies, Canberra.

Symonds, D.L. 1985. A history of British atomic tests in Australia. Australian Government Publishing Service, Canberra.

White, I.M. 1977. 'From camp to village: some problems of adaptation', in R.M. Berndt (ed.) Aborigines and change: Australia in the 70s. Humanities Press, New Jersey.

White, I.M. 1985. 'Mangkatina: woman of the desert', in I. White, D. Barwick and B. Meehan (eds) Fighters and singers: the lives of some Australian Aboriginal women. George Allen and Unwin, Sydney. 